This article was downloaded by: [Wingren, Anette Gjörloff]

On: 27 August 2008

Access details: Access Details: [subscription number 901930722]

Publisher Informa Healthcare

Informa Ltd Registered in England and Wales Registered Number: 1072954 Registered office: Mortimer House, 37-41 Mortimer Street, London W1T 3JH, UK

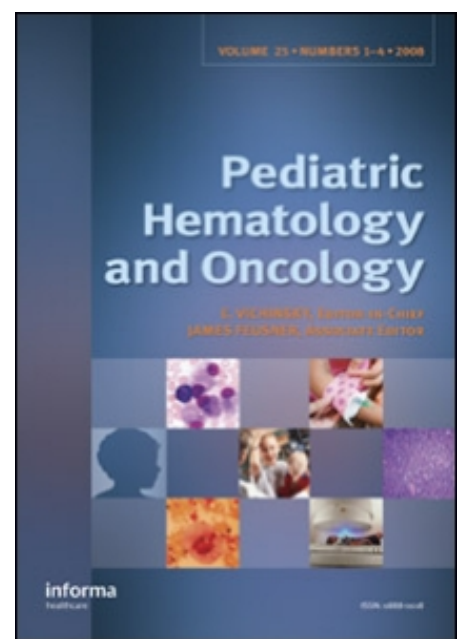

Pediatric Hematology and Oncology

Publication details, including instructions for authors and subscription information:

http://www.informaworld.com/smpp/title content=t713610311

\title{
IMMUNOHISTOCHEMICAL ANALYSES OF PHOSPHATASES IN CHILDHOOD B-CELL LYMPHOMA: Lower Expression of PTEN and HePTP and Higher Number of Positive Cells for Nuclear SHP2 in B-Cell Lymphoma Cases Compared to Controls
}

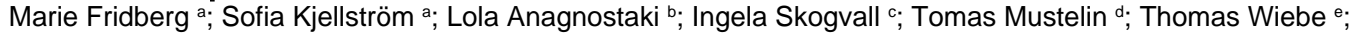
Jenny L. Persson b; Michael Dictor c; Anette Gjörloff Wingren to

${ }^{a}$ Department of Tumor Biology, Lund University, Malmö University Hospital, Malmö, Sweden ${ }^{b}$ Department of Pathology, Lund University, Malmö University Hospital, Malmö, Sweden ' Department of Pathology, Lund University, Lund, Sweden ${ }^{d}$ Laboratory of Signal Transduction, The Burnham Institute, La Jolla, California, USA e Department of Pediatrics, Lund University, Lund, Sweden ${ }^{\dagger}$ Department of Biomedical Laboratory Science, Health and Society, Malmö University, Malmö, Sweden ${ }^{9}$ Malmö University Hospital, Malmö, Sweden

Online Publication Date: 01 August 2008

To cite this Article Fridberg, Marie, Kjellström, Sofia, Anagnostaki, Lola, Skogvall, Ingela, Mustelin, Tomas, Wiebe, Thomas, Persson, Jenny L., Dictor, Michael and Wingren, Anette Gjörloff(2008)'IMMUNOHISTOCHEMICAL ANALYSES OF PHOSPHATASES IN CHILDHOOD B-CELL LYMPHOMA: Lower Expression of PTEN and HePTP and Higher Number of Positive Cells for Nuclear SHP2 in B-Cell Lymphoma Cases Compared to Controls',Pediatric Hematology and Oncology,25:6,528 — 540

To link to this Article: DOI: $10.1080 / 08880010802237054$

URL: http://dx.doi.org/10.1080/08880010802237054

\section{PLEASE SCROLL DOWN FOR ARTICLE}

Full terms and conditions of use: http://www.informaworld.com/terms-and-conditions-of-access.pdf

This article may be used for research, teaching and private study purposes. Any substantial or systematic reproduction, re-distribution, re-selling, loan or sub-licensing, systematic supply or distribution in any form to anyone is expressly forbidden.

The publisher does not give any warranty express or implied or make any representation that the contents will be complete or accurate or up to date. The accuracy of any instructions, formulae and drug doses should be independently verified with primary sources. The publisher shall not be liable for any loss, actions, claims, proceedings, demand or costs or damages whatsoever or howsoever caused arising directly or indirectly in connection with or arising out of the use of this material. 


\title{
IMMUNOHISTOCHEMICAL ANALYSES OF PHOSPHATASES IN CHILDHOOD B-CELL LYMPHOMA: Lower Expression of PTEN and HePTP and Higher Number of Positive Cells for Nuclear SHP2 in B-Cell Lymphoma Cases Compared to Controls
}

\author{
Marie Fridberg and Sofia Kjellström $\square \quad$ Department of Tumor Biology, Lund \\ University, Malmö University Hospital, Malmö, Sweden
}

Lola Anagnostaki $\square \quad$ Department of Pathology, Lund University, Malmö University Hospital, Malmö, Sweden

\author{
Ingela Skogvall $\square \quad$ Department of Pathology, Lund University, Lund, Sweden \\ Tomas Mustelin $\quad \square \quad$ Laboratory of Signal Transduction, The Burnham Institute, La \\ Jolla, California, USA
}

Thomas Wiebe $\square \quad$ Department of Pediatrics, Lund University, Lund, Sweden

Jenny L. Persson $\square \quad$ Department of Pathology, Lund University, Malmö University Hospital, Malmö, Sweden

Michael Dictor $\square \quad$ Department of Pathology, Lund University, Lund, Sweden

\begin{abstract}
Anette Gjörloff Wingren $\square \quad$ Department of Biomedical Laboratory Science, Health and Society, Malmö University, Malmö, Sweden; and Malmö University Hospital, Malmö, Sweden
\end{abstract}

\begin{abstract}
$\square \quad$ Although many pediatric B-cell lymphoma patients are being cured today, much is still unknown about the pathogenesis of this disease. Protein tyrosine phosphatases are involved in the control of survival, growth, and differentiation of cells. The authors have analyzed 26 pediatric B-cell lymphoma cases for the expression of a panel of phosphatases and report a statistically significant lower expression intensity of PTEN and HePTP and higher nuclear SHP2 expression in B-cell
\end{abstract}

Received 7 September 2007; accepted 28 May 2008.

The authors thank Elise Nilsson for invaluable technical assistance. This work was supported by grants from the American Cancer Society for technology transfer, the Swedish Childrens Cancer Foundation, the Alfred Österlund Foundation, the Magnus Bergvall Foundation, the Medical Faculty of Lund, Svenska Läkaresällskapet, the Siv-Inger and Per-Erik Andersson Foundation, the Berta Kamprad Foundation, the Cancer Foundation at Malmö University Hospital, and the Ellen Bachrach's Children's Cancer Foundation of Haematology.

Address correspondence to Anette Gjörloff Wingren, Department of Biomedical Laboratory Science, Health and Society, Malmö University, Malmö, Sweden. E-mail: anette.gjorloff-wingren@hs.mah.se 
lymphoma cases compared to lymphoid tissue. Knowledge about the expression of key regulatory proteins in pediatric B-cell lymphomas is necessary for revealing the complex molecular background of this disease.

Keywords Burkitt, immunohistochemistry, lymphoma, pediatric, protein tyrosine phosphatase

Non-Hodgkin lymphoma (NHL) in children is primarily limited to four types of lymphoma: Burkitt lymphoma (BL), lymphoblastic lymphoma, diffuse large B-cell lymphoma (DLBCL), and anaplastic large cell lymphoma (ALCL), where BL is the most common subgroup, constituting about $40 \%$ of the cases [1]. BL is a highly aggressive lymphoma, with tumor cells that have a high proliferation rate and are phenotypically characterized by being $\mathrm{CD}_{10} 0^{+}, \mathrm{bcl}^{+}$, and bcl2- [2]. A high survival rate is obtained in children with pediatric BL today, due to effective therapeutic chemotherapy. However, precise diagnosis based on histologic, immunophenotypic, and genetic features is still critical when planning for the appropriate therapy [3]. The majority of BL and DLBCL have been suggested to be derived from lymph node germinal center (GC) regions, where rapidly proliferating Bcell blasts undergo somatic hypermutation of the immunoglobulin variable region gene during their differentiation to antibody-secreting plasma cells or memory B cells [4]. During the GC process, the B cells transform into malignant BL or DLBCL by either activation of proto-oncogenes or disruption of tumor suppressor genes.

Cells of the immune system, and thereby lymphoma, utilize a wide array of signaling networks, evoked by multiple cell surface receptors [5]. Reversible tyrosine phosphorylation of proteins is catalyzed by protein tyrosine kinases (PTKs) and protein tyrosine phosphatases (PTPs) and functions as a key regulatory mechanism for a broad set of physiological processes in eukaryotes [6]. By dephosphorylating protein substrates, PTPs counteract the phosphorylating PTKs, and abnormalities in this process cause dysfunctional cell signaling and have been reported in many inherited or acquired human diseases. It is now known that 107 genes in the human genome encode members of four PTP families [7]. The largest group is the classical PTPs, comprising of 21 transmembrane and 17 nonreceptor PTPs $[7,8]$.

Here, we provide novel data about the expression of nonreceptor phosphatases Src homology (SH) 2 domain-containing phosphatase (SHP) 1, SHP2, phosphatase and tensin homolog (PTEN), and hematopoietic PTP (HePTP) in pediatric control lymphoid tissue and B-cell lymphoma tissue from children diagnosed with BL, DLBCL, or unspecified B-cell NHL. We show a lower staining intensity for cytoplasmic PTEN and HePTP in B-cell lymphoma tissue compared to control lymphoid tissue. Nuclear SHP2 was detected in a higher percentage of B cells in BL and LBCL cases 
compared to controls, whereas no significant differences were found in cytoplasmic SHP1 or SHP2 expression between normal and malignant B cells. Investigating the expression of key regulatory proteins in cell signaling pathways frequently mutated in cancer is of great importance for revealing the molecular background of pediatric lymphomas, and for designing better individual treatment of this disease in the future.

\section{MATERIALS AND METHODS}

\section{Case Selection}

Twenty-six formalin-fixed and paraffin-embedded lymphoid tissue samples of pediatric B-cell NHL lymphoma diagnosed at the University Hospital in Lund, Sweden, between 1982 and 2006, were reviewed and selected by two hematopathologists. Cases included in the study displayed classic morphologic and immunophenotypic features in accordance with WHO and Revised European-American classification criteria. The patients were children of the ages 1 to 17 years and the samples represented $19 \mathrm{BL}$, 2 DLBCL, 1 LBCL, and 4 cases diagnosed with "B-cell NHL" (B-NHL). Formalin-fixed and paraffin-embedded nonmalignant tonsils from 5 children were included as controls.

\section{Immunohistochemical Methods}

Representative areas in the paraffin blocks were chosen by a pathologist and a tissue microarray (TMA) was constructed as described previously [9]. In addition, one control TMA consisting of 5 cases of pediatric nonmalignant tonsils was constructed. Four-micrometer TMA sections were dried, deparaffinized, rehydrated, and microwave-treated for $10 \mathrm{~min}$ with target retrieval solution, $\mathrm{pH}$ 9.9. The sections were subsequently processed in an automatic immunohistochemistry staining machine (Techmate 500; Dako, Copenhagen, Denmark) with the following primary antibodies: mouse anti-human CD10 (Serotec, Oxford, UK), mouse anti-human Bcl6 (Chemicon/Millipore, Bedford, MA, USA), rabbit anti-human SHP1 and SHP2 (Santa Cruz Biotechnology, Santa Cruz, USA), rabbit anti-human PTEN and mouse anti-human PCNA (Cell Signaling, Danvers, MA, USA), mouse anti-human HePTP [10], and mouse anti-human Bcl2 and mouse anti-human CD3 (Dako Cytomation, Copenhagen, Denmark). Incubation with secondary antibodies and visualization were performed with Dako real envision detection system peroxidase/DAB (Dako). Slides were counterstained with hematoxylin. All cases were blinded and analyses were performed independently by one pathologist and two researchers.

Due to poor quality in some material, all markers could not be validated in all samples. Staining intensity and percent stained tumor cells were 
validated independently. The intensity was graded 0 if the case was negative for the marker, 1 if a weak staining was detected, 2 for a moderate staining, and 3 for a strong staining. For each marker, the staining intensity in the different tissue samples was scored in relation to the other cases on the same slide. Further, since normal controls in the case of HePTP displayed a stronger intensity compared to lymphoma cases, the normal controls were here given an additional grade 4 for statistical analyses. For scoring percent stained tumor cells, a $25 \%$ cutoff was used; $26-50 \%$ was considered an intermediate expression and $51-100 \%$ a high protein expression. In the nonmalignant TMA, the mature B cells were analyzed. There was a $90 \%$ agreement between the observers and, in cases of variance, the pathologist determined the outcome. For statistical analysis, Mann-Whitney tests were performed in SPSS for Windows 12.0.1 (2002, SPSS Inc.).

\section{RESULTS}

\section{Patient Population}

Tissue samples from 26 pediatric patients diagnosed with B-cell lymphomas, including 19 BL, 2 DLBCL, 1 LBCL (diagnosis indicates DLBCL or follicular lymphoma grade 3B), and 4 B-NHL, were analyzed in this study. The 2 DLBCL cases and the LBCL case were grouped together as LBCL. The median age was 8 years and the majority of cases were boys (Table 1). In 15 out of $19 \mathrm{BL}$ cases, tumors presented in the gastrointestinal tract and 14 of 19 BL involved extranodal sites. Also in BL, 7 out of 19 were diagnosed with stage I-II and 12 out of 19 with stage III-IV, according to Murphy staging system. Five out of 7 of the LBCL and unspecified B-NHL cases were graded as stage III-IV. Recurrence was not found in any BL case but in 1 LBCL and in 1 B-NHL patient (Table 1). The overall survival was $100 \%$ in the study population.

\section{Highly Proliferating and GC-derived Tumors in the Majority of B-cell Lymphoma Cases}

The samples were stained for the GC markers CD10 and Bcl6, for Bcl2 and CD3, and for the proliferation marker PCNA (Table 2). With a 25\% cutoff, 13 out of 16 analyzed BL were positive for CD10, demonstrating that the majority of BL tumors in this study are derived from GC B cells. The majority of BL cells were also positive for Bcl6. Two out of 3 LBCL and 3 out of 4 B-NHL cases were positive for CD10, also indicating that the tumor cells originate from mature, activated B cells. The anti-apoptotic marker Bcl2 was expressed in 5 out of 14 analyzed cases of BL, in 1 out of 3 LBCL and in 3 out of 4 B-NHL cases. PCNA staining analysis showed a very high proliferation index of the tumor cells in all cases. Infiltrating $\mathrm{T}$ cells were visualized by 
TABLE 1 Clinical Features of the B-cell Lymphoma Cases Included in the Study

\begin{tabular}{|c|c|c|c|c|c|}
\hline & Sex & Age & Stage $^{a}$ & Nodal/extranodal sites & Recurrence \\
\hline \multicolumn{6}{|c|}{ BL patient } \\
\hline 1 & M & 11 & III & extranodal & no \\
\hline 2 & M & 10 & III & extranodal & no \\
\hline 3 & $\mathrm{~F}$ & 1 & III & nodal & no \\
\hline 4 & M & 4 & IV & nodal + extranodal & no \\
\hline 5 & M & 7 & I & nodal & no \\
\hline 6 & M & 17 & III & extranodal & no \\
\hline 7 & M & 8 & III & nodal & no \\
\hline 8 & M & 16 & II & extranodal & no \\
\hline 9 & M & 8 & III & extranodal & no \\
\hline 10 & M & 12 & I & nodal & no \\
\hline 11 & M & 8 & III & extranodal & no \\
\hline 12 & M & 7 & IV & extranodal & no \\
\hline 13 & $\mathrm{~F}$ & 6 & II & extranodal & no \\
\hline 14 & M & 9 & I & nodal & no \\
\hline 15 & M & 6 & IV & nodal + extranodal & no \\
\hline 16 & M & 14 & IV & extranodal & no \\
\hline 17 & M & 5 & II & extranodal & no \\
\hline 18 & M & 11 & II & extranodal & no \\
\hline 19 & M & 6 & III & extranodal & no \\
\hline \multicolumn{6}{|c|}{ (D)LBCL patient } \\
\hline 1 & $\mathrm{~F}$ & 12 & III & extranodal & no \\
\hline 2 & $\mathrm{~F}$ & 6 & III & extranodal & no \\
\hline 3 & $\mathrm{~F}$ & 17 & II & nodal + extranodal & yes \\
\hline \multicolumn{6}{|c|}{ B-NHL patient } \\
\hline 1 & $\mathrm{~F}$ & 2 & IV & extranodal & no \\
\hline 2 & M & 17 & III & extranodal & no \\
\hline 3 & M & 4 & II & nodal & no \\
\hline 4 & M & 15 & IV & extranodal & yes \\
\hline
\end{tabular}

${ }^{a}$ Staging is determined according to the Murphy staging system.

Note. Tissue samples were from 26 pediatric patients diagnosed with B-cell lymphomas, including $19 \mathrm{BL}, 2$ DLBCL, 1 LBCL (indicating DLBCL or follicular lymphoma grade 3B), and 4 unspecified B-NHL. The median age was 8 years and the majority of the cases were boys $(\mathrm{M})$.

staining with a CD3 antibody and 4 out of the 13 analyzed BL cases displayed T cells above the cutoff level (25\%). The LBCL cases were negative for CD3positive T cells, whereas high numbers $(>50 \%)$ of $\mathrm{T}$ cells were detected in 3 out of 4 B-NHL cases (Table 2).

\section{The Expression of PTPs SHP1, SHP2, PTEN, and HePTP in Control Lymphoid Tissue}

Initially, lymphoid cells (tonsils) from 5 children were included in the study, stained, and analyzed for SHP1, SHP2, PTEN, and HePTP expression (Figure 1, Tables 3-5). SHP1 was found exclusively in the cytoplasm with intensities graded between 1 and 3 . In 4 out of 5 controls, the expression in terms of percent stained B cells was high, 51-100\% (Figure 1, Table 
TABLE 2 Proliferation Index and the Expression of CD10, Bcl6, Bcl2, and CD3 in the B-cell Lymphoma Tumors

\begin{tabular}{|c|c|c|c|c|c|}
\hline & CD10 pos/neg & Bcl6 pos/neg & Proliferation (PCNA) & $\mathrm{Bcl} 2 \mathrm{pos} / \mathrm{neg}$ & CD3\% \\
\hline \multicolumn{6}{|c|}{ BL patient } \\
\hline 1 & - & - & high & + & - \\
\hline 2 & + & + & high & - & - \\
\hline 3 & + & + & n.d. & - & n.d. \\
\hline 4 & + & + & high & - & + \\
\hline 5 & + & + & high & + & + \\
\hline 6 & + & + & high & - & - \\
\hline 7 & + & + & high & + & - \\
\hline 8 & - & + & high & + & - \\
\hline 9 & + & - & high & - & - \\
\hline 10 & + & + & high & - & - \\
\hline 11 & + & + & high & - & + \\
\hline 12 & + & + & high & - & + \\
\hline 13 & - & - & high & - & - \\
\hline 14 & n.d. & - & n.d. & n.d. & n.d. \\
\hline 15 & + & - & n.d. & n.d. & n.d. \\
\hline 16 & + & - & high & + & - \\
\hline 17 & + & + & n.d. & n.d. & n.d. \\
\hline 18 & n.d. & n.d. & n.d. & n.d. & n.d. \\
\hline 19 & n.d. & n.d. & n.d. & n.d. & n.d. \\
\hline \multicolumn{6}{|c|}{$\begin{array}{l}\text { (D)LBCL } \\
\text { patient }\end{array}$} \\
\hline 1 & + & + & high & + & - \\
\hline 2 & + & - & high & - & - \\
\hline 3 & - & - & high & - & - \\
\hline \multicolumn{6}{|c|}{$\begin{array}{l}\text { B-NHL } \\
\text { patient }\end{array}$} \\
\hline 1 & + & + & high & - & - \\
\hline 2 & + & + & high & + & + \\
\hline 3 & + & - & high & + & + \\
\hline 4 & - & - & high & + & + \\
\hline
\end{tabular}

Note. n.d. indicates no data due to poor tissue quality or that the samples have not been stained. The samples were stained for the GC markers CD10 and Bcl6, for Bcl2 and CD3, and for the proliferation marker PCNA. For scoring percent positively stained tumor cells, a 25\% cutoff was used. $0-25 \%$ was considered a negative (-) protein expression and $26-100 \%$ a positive $(+)$ protein expression.

3). SHP2 was found in both cytoplasm and nucleus and the cytoplasmic intensity was graded 3 in 4 out of 5 controls (Figure 1 and Table 3). Further, all controls showed cytoplasmic SHP2 staining in a high percentage of the B cells, 51-100\%, (Table 4) and the nuclear staining ranged between 10 and $40 \%$ positive cells (Table 5). PTEN was expressed in both cytoplasm and nucleus in lymphoid B cells in the control tissue. The staining intensity for cytoplasmic PTEN was graded intermediate to high (grades 2-3) and in all cases a high percentage (51-100\%) of cells expressed the protein (Tables 3 and 4). Nuclear PTEN staining was found in 20-40\% of the control B cells (Table 5). HePTP was found exclusively in the cytoplasm in all cases and all the controls showed a strong HePTP intensity in a high percentage of cells (Figure 1, Tables 3 and 4). 

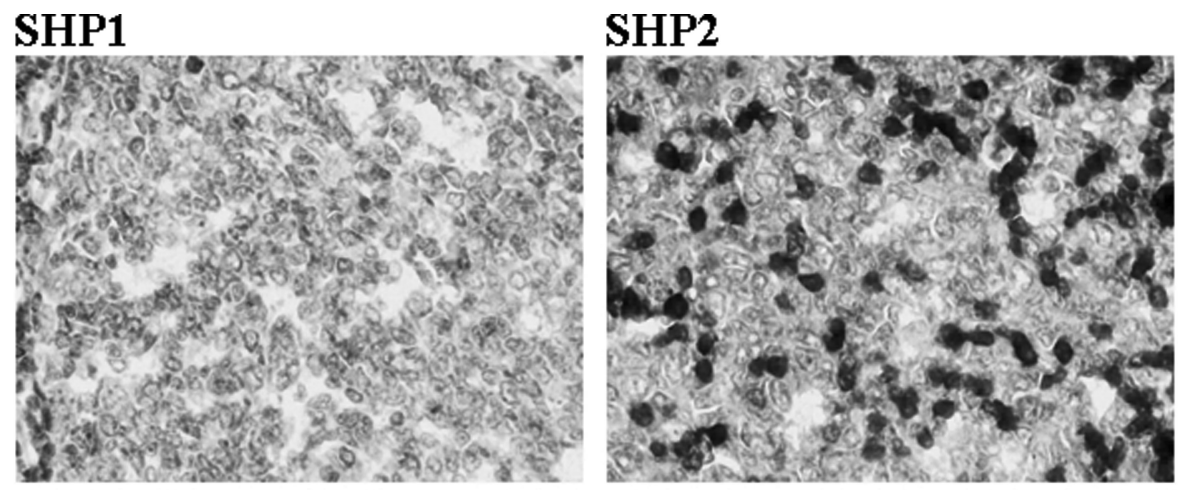

\section{PTEN}

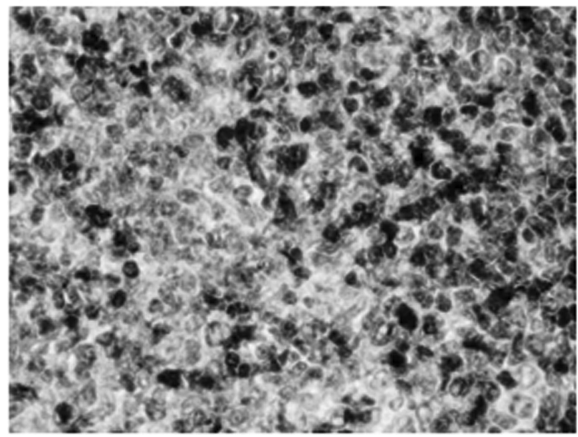

\section{HePTP}

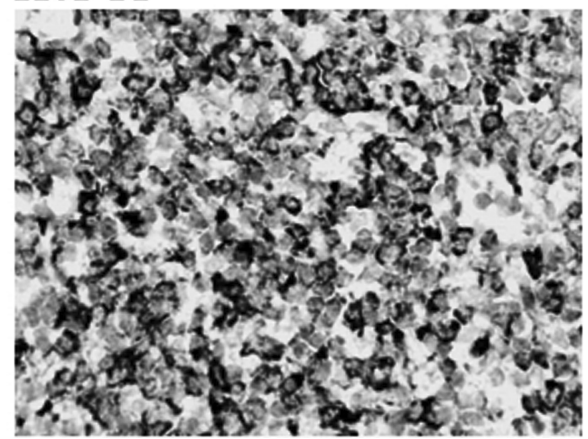

FIGURE 1 The expression of SHP1, SHP2, PTEN, and HePTP in pediatric tonsil control tissue. Staining intensity and percent stained cells were analyzed in mature B cells.

\section{Significantly Lower Staining Intensity of Cytoplasmic PTEN and HePTP but Higher Nuclear SHP2 Expression in BL Cases Compared to Control Lymphoid Tissue}

In total, $19 \mathrm{BL}, 3 \mathrm{LBCL}$, and 4 unspecified B-NHL cases were stained and analyzed for the expression of SHP1, SHP2, PTEN, and HePTP (Figure 2, Tables 3-5). As in the control tissue, SHP1 and HePTP were found in the cytoplasm, whereas SHP2 and PTEN were expressed in both cytoplasm and nucleus. Cytoplasmic staining intensity and percent positively stained cells were determined and presented in Tables 3 and 4. The staining results obtained for either the BL cases alone or all lymphoma cases, respectively, were compared to normal controls in a Mann-Whitney test. When the BL cases alone were analyzed for statistical calculations and comparisons to control tissue, the statistical results were similar to those obtained for all B-cell lymphoma cases (Tables 3-5).

The analysis revealed that the staining intensity for cytoplasmic PTEN and HePTP were significantly lower in B-cell lymphoma tissue compared to controls, but no differences in percent positively stained cells could 
TABLE 3 Lower PTEN and HePTP Staining Intensity in B-cell Lymphoma Cases

Compared to Controls

\begin{tabular}{|c|c|c|c|c|}
\hline & Control B cells $(N)$ & $\mathrm{BL}(N)$ & (D)LBCL $(N)$ & B-NHL $(N)$ \\
\hline \multicolumn{5}{|l|}{ SHP1 } \\
\hline 0 & 0 & 1 & 0 & 1 \\
\hline 1 & 1 & 5 & 1 & 0 \\
\hline 2 & 3 & 6 & 0 & 1 \\
\hline 3 & 1 & 7 & 2 & 2 \\
\hline 4 & 0 & 0 & 0 & 0 \\
\hline Total & 5 & 19 & 3 & 4 \\
\hline$p$ value (control $\mathrm{B} / \mathrm{BL}$ ) & .945 & & & \\
\hline$p$ value (control $\mathrm{B} /$ all $\mathrm{L}$ ) & .815 & & & \\
\hline \multicolumn{5}{|l|}{ SHP2 } \\
\hline 0 & 0 & 0 & 0 & 0 \\
\hline 1 & 0 & 2 & 2 & 2 \\
\hline 2 & 4 & 9 & 1 & 1 \\
\hline 3 & 1 & 5 & 0 & 1 \\
\hline 4 & 0 & 0 & 0 & 0 \\
\hline Total & 5 & 16 & 3 & 4 \\
\hline$p$ value (control $\mathrm{B} / \mathrm{BL}$ ) & .968 & & & \\
\hline$p$ value (control $\mathrm{B} /$ all $\mathrm{L}$ ) & .641 & & & \\
\hline \multicolumn{5}{|l|}{ PTEN } \\
\hline 0 & 0 & 3 & 0 & 0 \\
\hline 1 & 0 & 8 & 0 & 2 \\
\hline 2 & 3 & 4 & 2 & 1 \\
\hline 3 & 2 & 2 & 1 & 1 \\
\hline 4 & 0 & 0 & 0 & 0 \\
\hline Total & 5 & 17 & 3 & 4 \\
\hline$p$ value (control $\mathrm{B} / \mathrm{BL}$ ) & .025 & & & \\
\hline$p$ value (control $\mathrm{B} /$ all $\mathrm{L}$ ) & .051 & & & \\
\hline \multicolumn{5}{|l|}{ НеРТР } \\
\hline 0 & 0 & 2 & 0 & 1 \\
\hline 1 & 0 & 6 & 1 & 1 \\
\hline 2 & 0 & 3 & 1 & 2 \\
\hline 3 & 0 & 5 & 1 & 0 \\
\hline 4 & 5 & 0 & 0 & 0 \\
\hline Total & 5 & 16 & 3 & 4 \\
\hline$p$ value (control $\mathrm{B} / \mathrm{BL}$ ) & $<.001$ & & & \\
\hline$p$ value (control $\mathrm{B} /$ all $\mathrm{L}$ ) & $<.001$ & & & \\
\hline
\end{tabular}

Note. The pediatric B-cell lymphoma and lymphoid control tissue were stained and analyzed for the cytoplasmic expression of SHP1, SHP2, PTEN, and HePTP. The staining intensity was graded $0=$ negative, $1=$ weak, 2 moderate, $3=$ strong, $4=$ very strong. The staining results obtained for either the BL cases alone or all lymphoma cases (all L), respectively, were compared to normal controls in a Mann-Whitney test.

be detected (Tables 3 and 4). No significant differences between B-cell lymphoma and controls were observed for SHP1 and SHP2 in staining intensity. SHP1 proved to be similarly expressed in malignant and control tissue, in both staining intensity and percent positively stained cells. No significant differences were found between controls and tumor cells for any of the cytoplasmic proteins (Table 4). Nuclear SHP2 was found to be 
TABLE 4 No Difference between Control and B-Cell Lymphoma Cases in Percent Stained B-Cells for Cytoplasmic SHP1, SHP2, PTEN, and HePTP

\begin{tabular}{|c|c|c|c|c|}
\hline & Control B cells $(N)$ & $\operatorname{BL}(N)$ & (D) LBCL $(N)$ & B-NHL $(N)$ \\
\hline \multicolumn{5}{|l|}{ SHP1 } \\
\hline $0-25 \%$ & 0 & 4 & 1 & 1 \\
\hline $26-50 \%$ & 1 & 6 & 0 & 0 \\
\hline $51-100 \%$ & 4 & 9 & 2 & 3 \\
\hline Total & 5 & 19 & 3 & 4 \\
\hline$p$ value (control $\mathrm{B} / \mathrm{BL}$ ) & 0.235 & & & \\
\hline$p$ value (control $\mathrm{B} /$ all $\mathrm{L}$ ) & 0.305 & & & \\
\hline \multicolumn{5}{|l|}{ SHP2 } \\
\hline $0-25 \%$ & 0 & 0 & 0 & 0 \\
\hline $26-50 \%$ & 0 & 0 & 0 & 0 \\
\hline $51-100 \%$ & 5 & 16 & 3 & 4 \\
\hline Total & 5 & 16 & 3 & 4 \\
\hline$p$ value (control $\mathrm{B} / \mathrm{BL}$ ) & 1.000 & & & \\
\hline$p$ value (control $\mathrm{B} /$ all $\mathrm{L}$ ) & 1.000 & & & \\
\hline \multicolumn{5}{|l|}{ PTEN } \\
\hline $0-25 \%$ & 0 & 3 & 0 & 1 \\
\hline $26-50 \%$ & 0 & 5 & 1 & 1 \\
\hline $51-100 \%$ & 5 & 9 & 2 & 2 \\
\hline Total & 5 & 17 & 3 & 4 \\
\hline$p$ value (control $\mathrm{B} / \mathrm{BL}$ ) & 0.120 & & & \\
\hline$p$ value (conrol $\mathrm{B} /$ all $\mathrm{L}$ ) & 0.114 & & & \\
\hline \multicolumn{5}{|l|}{ НеРТР } \\
\hline $0-25 \%$ & 0 & 3 & 0 & 1 \\
\hline $26-50 \%$ & 0 & 3 & 0 & 2 \\
\hline $51-100 \%$ & 5 & 10 & 3 & 1 \\
\hline Total & 5 & 16 & 3 & 4 \\
\hline$p$ value (control $\mathrm{B} / \mathrm{BL}$ ) & 0.240 & & & \\
\hline$p$ value (control $\mathrm{B} /$ all $\mathrm{L}$ ) & 0.193 & & & \\
\hline
\end{tabular}

Note. The pediatric B-cell lymphoma and lymphoid control tissue were stained and analyzed for percentage of stained B-cells for cytoplasmic SHP1, SHP2, PTEN, and HePTP. For scoring percent stained cells, a $25 \%$ cutoff was used. $26-50 \%$ was considered an intermediate expression and $51-100 \%$ a high protein expression. The staining results obtained for either the BL cases alone or all lymphoma cases (all L), respectively, were compared to normal controls in a Mann-Whitney test.

expressed in a higher percentage of B cells in BL and LBCL cases compared to controls, whereas 3 out of 4 cases diagnosed with unspecified B-NHL displayed similar levels of nuclear SHP2 as the controls (Table 5).

\section{DISCUSSION}

Tyrosine phosphorylation is a key mechanism for signal transduction in multicellular organisms and processes that are regulated by this system include activation, proliferation, differentiation, cell motility, and transportation of molecules into or out of cells $[8,11,12]$. In this limited study of pediatric nonlymphoblastic B-cell lymphoma, a correlation with earlier findings $[3,13]$ was found with numbers of BL patients who presented with 
TABLE 5 B-cell Lymphoma Cases Display Nuclear SHP2 in a Higher Percentage of B-cells Compared to Controls

\begin{tabular}{lcccc}
\hline & Control B cells $(N)$ & BL $(N)$ & $(\mathrm{D})$ LBCL $(N)$ & B-NHL $(N)$ \\
\hline SHP2 & 1 & & & \\
$\quad 0-25 \%$ & 4 & 2 & 0 & 1 \\
$26-50 \%$ & 0 & 0 & 0 & 0 \\
$51-100 \%$ & 5 & 14 & 3 & 3 \\
Total & .008 & 16 & 3 & \\
$p$ value (control B/BL) & .019 & & & 1 \\
$p$ value (control B/all L) & & & & \\
PTEN & 2 & 11 & 0 & 4 \\
$\quad 0-25 \%$ & 3 & 4 & 1 & \\
$26-50 \%$ & 0 & 2 & 3 & \\
$\quad 51-100 \%$ & 5 & 17 & & \\
Total & .493 & & & \\
$p$ value (control B/BL) & .716 & & & \\
$p$ value (control B/all L) & & & & \\
\hline
\end{tabular}

Note. The pediatric B-cell lymphoma and lymphoid control tissue were stained and analyzed for the nuclear expression of SHP2 and PTEN. For scoring percent stained cells, a $25 \%$ cutoff was used. 26-50\% was considered an intermediate expression and 51-100\% a high protein expression. The staining results obtained for either the BL cases alone or all lymphoma cases (all L), respectively, were compared to normal controls in a Mann-Whitney test.

limited-stage disease I or II ( $35 \%$ in this study), while $65 \%$ had widespread disease, stage III or IV. The immunophenotype suggests a follicle center origin for BL [3]. Indeed, both BL and follicular lymphoma are derived from the GC stage of differentiation [14]. In our study, PCNA staining analysis showed a very high proliferation index of the pediatric tumor cells

BL
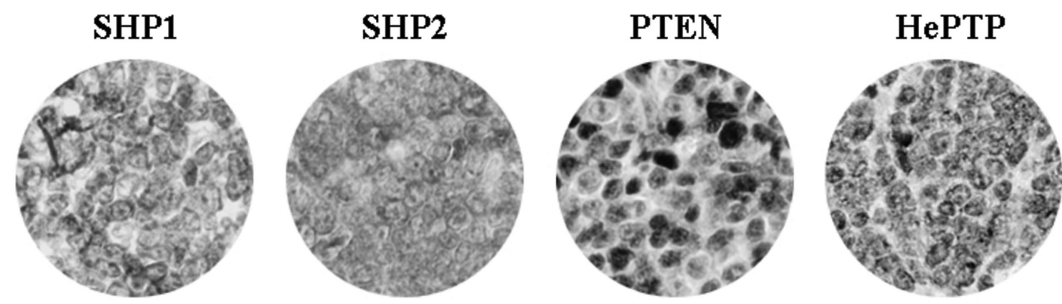

LBCL
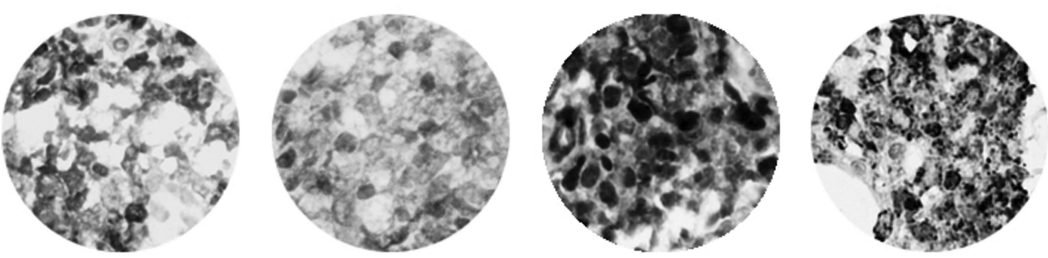

FIGURE 2 The expression of SHP1, SHP2, PTEN, and HePTP in one selected pediatric BL and one selected pediatric LBCL case. For the BL case, cytoplasmic staining intensity was graded 3 (SHP1), 3 (SHP2), 1 (PTEN), and 3 (HePTP). For the LBCL case, the staining intensity was graded 3 (SHP1), 1 (SHP2), 3 (PTEN), and 3 (HePTP). 
in all cases. In adult diffuse large B-cell lymphoma (DLBCL), two subgroups have been identified using cDNA microarrays, which differ in their ability to be cured by the multiagent chemotherapy that is used at present [15-17]. The GC subgroup expresses genes characteristic of normal GC B cells and has been associated with a better outcome, whereas the activated B-cell-like (ABC) group expresses genes characteristic of activated blood $\mathrm{B}$ cells and has been associated with a poor outcome. Bcl6, CD10, and MUM1/IRF4 have been shown to be differently expressed in the GC and non-GC subgroups using gene expression arrays as well as immunohistochemistry [15-18]. Both CD10 and Bcl6 are considered GC markers, while IRF4 has been found to be expressed in plasma cells and a subset of cells in the apical light zone of the GC [19-22]. We have analyzed 26 cases of pediatric B-cell lymphomas for the expression of SHP1, SHP2, PTEN, and HePTP and compared the expression to pediatric control lymphoid tissue. While SHP1 has been shown to be involved mainly as an antagonist to the growth-promoting potentials of receptor PTKs, the role of SHP2 is more complex, indicating both positive and negative roles [23, 24]. In this study, we detected no significant differences in SHP1 protein expression when comparing pediatric control lymphoid tissue and B-cell lymphoma tissue. Interestingly, nuclear SHP2 proved to be expressed in a higher percentage of cells in the BL and LBCL cases compared to controls, indicating a possible role for this proto-oncogene in lymphoma.

PTEN, together with p53, is the most frequently mutated tumor suppressor gene in human cancer [25]. In this context, PTEN functions as a lipid phosphatase, downregulating the PI3K-pathway by dephosphorylating its substrate phosphatidylinositol 3,4,5-triphosphate [26].

In a previous report by Butler et al. [30], somatic coding/splice site PTEN mutations was reported in $20 \%$ of BL cell lines and in $3 \%$ of primary NHL cases studied. We have shown that adult GC DLBCL cells display a lower staining intensity of PTEN compared to non-GC DLBCL cells [28] and here we report a significantly lower staining intensity of PTEN in the 17 analyzed pediatric BL samples compared to control lymphoid tissue. HePTP has been identified as an ERK 1/2 PTP and overexpression of HePTP in Jurkat T-cells blocks ERK 1/2 activation after engagement of the T-cell receptor [29-31]. In T-cells, HePTP also binds and dephosphorylates the mitogen-activated protein (MAP)-kinase family member p38 [32]. These findings indicate tumor suppressor functions for HePTP and in this study we show a lower staining intensity of this PTP in pediatric B-cell lymphomas compared to B cells in control lymphoid tissue. The importance of HePTP is emphasized by the findings that this PTP often is dysregulated in the preleukemic disorder myelodysplastic syndrome as well as in acute myelogenous leukemia [29].

In summary, here we provide novel information about the expression of SHP1, SHP2, PTEN, and HePTP in childhood B-cell lymphoma tumors 
and control B cells from children. Two out of 4 analyzed phosphatases, HePTP and PTEN, were downregulated in pediatric B-cell lymphoma tissue compared to lymphoid controls. HePTP is a negative regulator of T-cell antigen receptor signal transduction [32] and PTEN is one of the most frequently mutated tumor suppressor genes in human cancer [25]. Our results might indicate that the two enzymes potentially have a role also in pediatric B-cell lymphoma. BL is a highly aggressive lymphoma, with tumor cells of GC origin that have a high proliferation rate. Due to effective therapeutic chemotherapy, a high survival rate is obtained in children with pediatric BL today. However, precise diagnosis based on histologic, immunophenotypic, and genetic features is still critical. Therefore, knowledge about key enzymes involved in regulating cell signaling is of outmost importance for future improvement of pediatric cancer therapy.

\section{REFERENCES}

[1] Cairo MS, Raetz E, Perkins SL. Non-Hodgkin lymphoma in children. In: Kufe DW, Pollock RE, Weichselbaum RR, et al, eds. Cancer Medicine, ed 6. London: BC Decker; 2003.

[2] Cogliatti SB, Novak U, Henz S, et al. Diagnosis of Burkitt lymphoma in due time: a practical approach. BrJ Haematol. 2006;134:294-301.

[3] Ferry JA. Burkitts lymphoma: clinicopathologic features and differential diagnosis. The Oncologist. 2006;11:375-383.

[4] Dalla-Favera R, Gaidano G. Molecular biology of lymphomas. In: De Vita VT, Hellman S, Rosenberg SA, eds. Cancer: Principles and Practice of Oncology. Philadelphia: Lippincott Williams \& Wilkins; 2001: 2215-2235.

[5] Pao LI, Badour K, Siminovitch KA, Neel BG. Non-receptor tyrosine phosphatases in immune cell signaling. Annu Rev Immunol. 2007;25:473-523.

[6] Mustelin T, Vang T, Bottini N. Protein tyrosine phosphatases and the immune response. Nat Rev Immunol. 2005;5:43-57.

[7] Alonso A, Sasin J, Bottini N, et al. Protein tyrosine phosphatases in the human genome. Cell. 2004;117:699-711.

[8] Andersen JN, Jansen PG, Echwald SM, Mortensen OH, Fukada T, Del Vecchio R, Tonks NK, Möller NPH. A genomic perspective on protein tyrosine phosphatases: gene structure, pseudogenes, and genetic disease linkage. FASEB J. 2004;18:8-30.

[9] Kononen J, Bubendorf L, Kallioniemi A, et al. Tissue microarrays for high-throughput molecular profiling of tumor specimens. Nat. Med. 1998;844-847.

[10] Nika K, Hyunh H, Williams S, et al. Haematopoietic protein tyrosine phosphatase (HePTP) phosohorylation by cAMP-dependent protein kinase in T-cells: dynamics and subcellular location. Biochem J. 2004;378:335-342.

[11] Mustelin T, Abraham R T, Rudd CE, Alonso A, Merlo J. Protein tyrosine phosphorylation in T cell signaling. Front Biosci. 2002;7:918-969.

[12] Mustelin T. Src Family Tyrosine Kinases in Leukocytes. Austin, TX: Landes; 1994:1-155.

[13] Mustelin T, Rahmouni S, Bottini N, Alonso A. Role of protein tyrosine phosphatases in $\mathrm{T}$ cell activation. Immunol Rev. 2003;191:139-147

[14] Mustelin T, Taskén K. Positive and negative regulation of T-cell activation through kinases and phosphatases. Biochem J. 2003;371:15-27

[15] Diebold J. Burkitt lymphoma. In: Jaffe ES, Harris NL, Stein H, Vardiman JW, eds. World Health Organization Classification of Tumours: Pathology and Genetics of Tumours of the Haematopoietic and Lymphoid Tissues. Lyon: International Agency for Research on Cancer (IARC) Press; 2001:181-184.

[16] Jack A, Barrans S, Blythe D, Rawstron A. Demonstration of a germinal center immunophenotype in lymphomas by immunocytochemistry and flow cytometry. Methods Mol Med. 2005;115:65-91. 
[17] Alizadeh AA, Eisen MB, Davis RE, et al. Nature. 2000;403:503-511.

[18] Rosenwald A, Wright G, Chan WC, et al. The use of molecular profiling to predict survival after chemotherapy for diffuse large-B-cell lymphoma. N Engl J Med. 2002;346:1937-1947.

[19] Wright G, Tan B, Rosenwald A, Hurt EH, Wiestner A, Staudt LM. A gene expression-based method to diagnose clinically distinct subgroups of diffuse large B cell lymphoma. Proc Natl Acad Sci US A. 2003;100:9991-9996.

[20] Chang CC, McClintock S, Cleveland RP, et al. Immunohistochemical expression patterns of germinal center and activation B-cell markers correlate with prognosis in diffuse large B-cell lymphoma. Am J Surg Pathol. 2004;28:464-470.

[21] Hans CP, Weisenburger DD, Greiner TC, et al. Confirmation of the molecular classification of diffuse large B-cell lymphoma by immunohistochemistry using a tissue microarray. Blood. 2003;103:275-282.

[22] Natkunam Y, Warnke RA, Montgomery K, Falini B, van De Rijn M. Analysis of MUM1/IRF4 protein expression using tissue microarrays and immunohistochemistry. Mod Pathol. 2001;14:686-694.

[23] Falini B, Fizzotti M, Pucciarini A, et al. A monoclonal antibody (MUM1p) detects expression of the MUM1/IRF4 protein in a subset of germinal center B cells, plasma cells, and activated T cells. Blood. 2000;95:2084-2092.

[24] Bai M, Agnantis NJ, Skyrlas A, et al. Increased expression of the bcl6 and CD10 Proteins Is associated with increased apoptosis and proliferation in diffuse large B-cell lymphomas. Mod Pathol. 2003;16:471-480.

[25] Tautz L, Pellechia M, Mustelin T. Targeting the PTPome in human disease. Expert Opin Therapeut Targets. 2006;10:157-177.

[26] Ke Y, Lesperance J, Zhang EE, et al. Conditional deletion of Shp2 in the mammary gland leads to impaired lobulo-alveolar outgrowth and attenuated Stat5 activation. J Biol Chem. 2006;281:34374-34380.

[27] Sulis ML, Parsons R. PTEN: from pathology to biology. Trends Cell Biol. 2003;13:478-483.

[28] Fridberg M, Servin A, Anagnostaki L, et al Protein expression and cellular localization in two prognostic subgroups of diffuse large B-cell lymphoma: higher expression of ZAP70 and PKC-b II in the non-germinal center group and poor survival in patients deficient in nuclear PTEN. Leukemia and Lymphoma. 2007;48:2221-2232.

[29] Anzelon AN, Wu H, Rickert RC. Pten inactivation alters peripheral B lymphocyte fate and reconstitutes CD19 function. Nat Immunol. 2003;4:287-294.

[30] Butler MP, Wang SI, Chaganti RS, Parsons R, Dalla-Favera R. Analysis of PTEN mutations and deletions in B-cell non-Hodgkin's lymphomas. Genes Chromosomes Cancer. 1999;4:322-327.

[31] Saxena M, Williams S, Brockdorff J, Gilman J, Mustelin T. Inhibition of T cell signaling by mitogen-activated protein kinase-targeted hematopoietic tyrosine phosphatase (HePTP). J Biol Chem. 1999;274:11693-11700.

[32] Oh-hora M, Ogata M, Mori Y, et al. Direct suppression of TCR-mediated activation of extracellular signal-regulated kinase by leukocyte protein tyrosine phosphatase, a tyrosine-specific phosphatase. J Immunol. 1999;163:1282-1288. 